\title{
Requirements for safety and quality of intravenous immunoglobulin $\mathrm{G}$ preparations
}

\author{
Gunter H Rütter
}

\begin{abstract}
The increasing use of intravenous immunoglobulin-G preparations (IVIg) calls for evaluation of the requirements for quality and freedom from infection.

The WHO Requirements dating from 1982 have been surpassed by the majority of IVIg preparations. Three methods are used for ensuring safety from infection: the restrictive choice of donor, the precise introductory screening of every individual blood or plasma donation, and the additional active virus inactivation procedures that surpass the virus elimination of, for example, the Cohn-fractionation method. Although it is highly improbable that IVIg can transfer infections, this possibility cannot be completely ruled out even when all the GMP (good manufacturing practice) rules are observed most carefully. Increased safety from infection would be provided if blood and plasma donations were obtained nationally from unpaid voluntary donors and if an additional active viral inactivation procedure was introduced.
\end{abstract}

IVIg has assumed an important role in prophylaxis and therapy of bacterial and viral infectious diseases for a considerable period, as well as in the treatment of primary and secondary antibody deficiency syndromes.

Various new indications for IVIg have appeared during the last few years and have been described and reviewed many times in previous reports ${ }^{1-415}$ and in this supplement. IVIg therapy has gained increased importance in the treatment of HIV infections, ${ }^{2}$ and particularly in autoimmune diseases. ${ }^{5}$ Although it is highly unlikely that IVIg preparations have caused transferred infection, and even though a distinct improvement in the safety of these preparations has been achieved during the last 20 years, it is still necessary to define quality and safety standards.

of Research and

Development,

Münster, Germany

G H Rütter

Correspondence to:

Dr G H Rütter, Serapharm

GmbH, Münsterstrasse 109,

D-48155 Münster,

Germany.
QUALITY REQUIREMENTS OF IVIg PREPARATIONS

The WHO requirements for intravenous immunoglobulin preparations stem from 1982 and lay down minimum standards.
IVIg should be extracted from a pool of at least 1000 individual donors. The IgG preparations should contain at least $90 \%$ intact IgG and as small an amount of IgA concentration as possible, as well as being free from fragments and aggregates.

IVIg should be modified biochemically as little as possible and should possess opsonising and complement fixing characteristics as well as other natural biological characteristics.

All IgG subclasses should be present, where possible, in similar distribution as in normal human plasma. The immunoglobulins should meet WHO standards and be free from prekallikrein activator, kinins, plasmins, accumulating preservatives (stabilisers) and other damaging contaminants as far as possible. ${ }^{6}$

These requirements are clearly surpassed today by the majority of manufacturers. Acute intravenous side effects of IVIg preparations are therefore not a relevant problem today. $^{2}$

SAFETY REQUIREMENTS FROM INFECTION THROUGH IVIg

A risk of infection from human plasma preparations can never be completely ruled out. The point to be discussed therefore is which methods are at our disposal.

Both the national health authorities and the WHO have issued corresponding guidelines that guarantee to the greatest possible extent the safety of blood products. ${ }^{7}$ These mainly cover the following points:

1) The best possible quality of the initial plasma (blood or blood plasma donations)

A careful selection of donors is necessary. The guidelines issued by the EC on 14 June 1989 emphasise the importance of voluntary, unpaid blood donation. ${ }^{8}$ The careful medical examination of every individual donor as well as appropriate questionnaires for anonymously eliminating any "high-risk" donors constitute further safeguards.

\begin{tabular}{lc} 
Table 1 IgG subclasses in WHO reference plasma \\
\hline Subclasses & WHO reference plasma $100 \%$ IgG \\
\hline $\mathrm{IgG}_{1}$ & $60,0 \%$ \\
$\mathrm{IgG}_{2}$ & $29,4 \%$ \\
$\mathrm{IgG}_{3}$ & $6,5 \%$ \\
$\mathrm{IgG}_{4}$ & $4,1 \%$ \\
\hline
\end{tabular}


2) Initial screening

The precise introductory screening of every individual blood or plasma donation with individual tests for $\mathrm{HBsAg}$, Anti-HCV, Anti-HIV-1 and -2, syphilis serology and GPT/ALT should be guaranteed. Normal values of GPT/ALT should be required. These test results must be unequivocally negative according to the national donor guidelines, otherwise the blood or plasma donation must be rejected.

3) Virus-inactivation procedure

Although the majority of IVIg products are manufactured according to modified Cohnfractionation $^{9}$ (which leads to removal of transfusion-relevant viruses to a very high degree), today there is increasing demand to introduce further, active virus-inactivation procedures in the manufacture of IVIg for additional safety. However, neither optimal initial screening nor additional virus inactivation procedures can completely exclude the risk of infections, so that the quality of the initial plasma is particularly important.

The manufacturing process has to embody diverse precipitation, centrifugation, dialysis, filtration and other stages that lead to an effective elimination of human pathogenic viruses of clinical relevance.

Table 2 shows an overview of potential pathogens and their possible routes of transmission via blood or via blood derivatives, respectively. ${ }^{10}$

On the basis of epidemiological data, there are only five viruses relevant to blood and blood plasma derivatives. ${ }^{11}$

1) HIV-1

2) Hepatitis B Virus (HBV)

\section{Plasma fractionation and IVlg extraction}

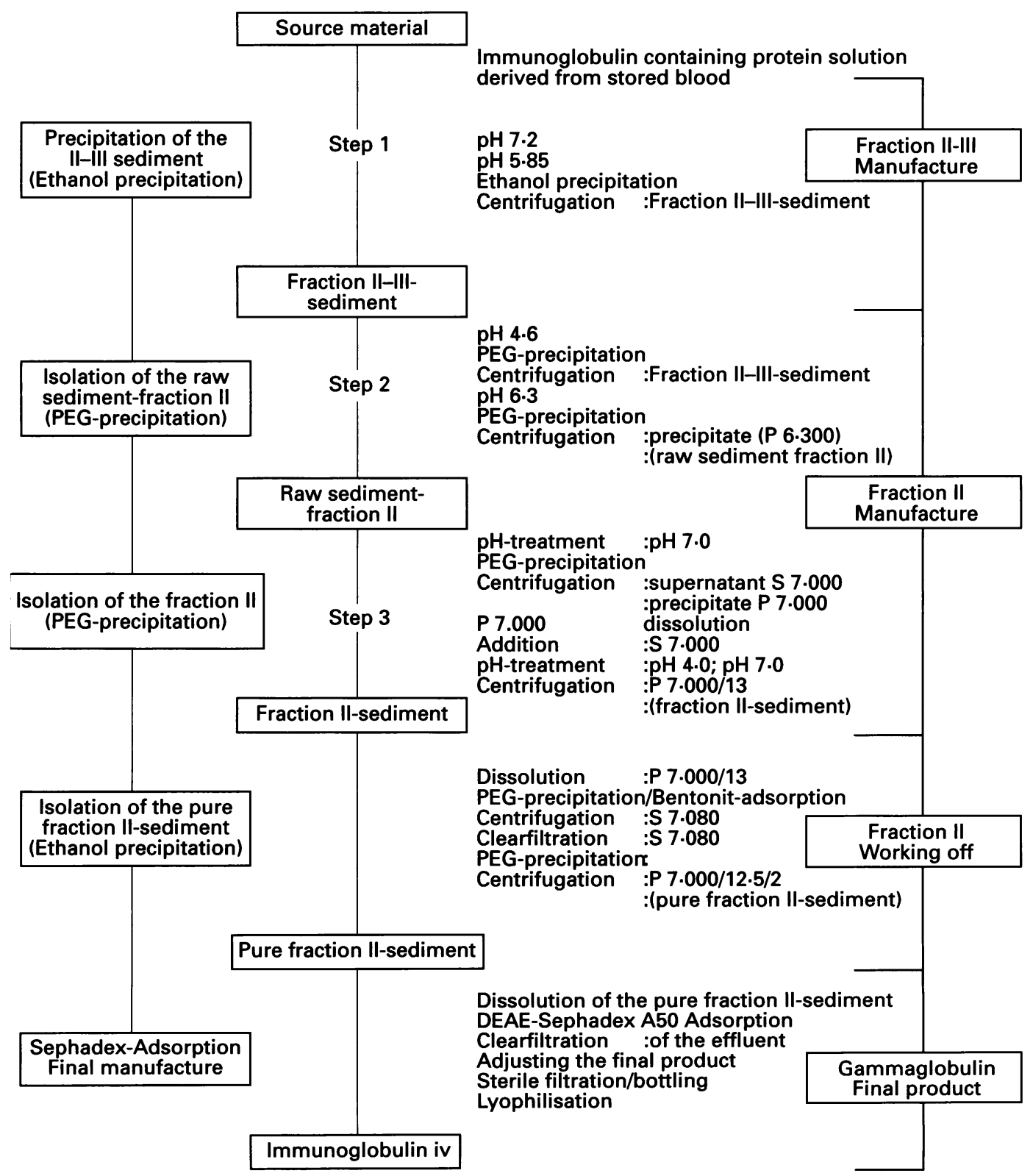

Flow Chart: Manufacturing procedure of IVIg, for example, on the basis of cold ethanol fractionation according to Cohn with some minor deviations. 
Table 2 Possible pathogens in blood and blood derivatives

\begin{tabular}{|c|c|c|c|}
\hline Viruses & $\begin{array}{l}\text { Lipoprotein- } \\
\text { envelope }\end{array}$ & Blood & $\begin{array}{l}\text { Blood- } \\
\text { derivatives }\end{array}$ \\
\hline $\begin{array}{l}\text { HBV } \\
\text { HDV } \\
\text { HNANB* (HCV) } \\
\text { HIV } \\
\text { HTLV-1 } \\
\text { CMV } \\
\text { EBV } \\
\text { Parvovirus B19 } \\
\text { HAV } \\
\text { Jakob-Creutzfeldt }\end{array}$ & $\begin{array}{l}+ \\
+ \\
+ \\
+ \\
+ \\
+ \\
+ \\
- \\
-\end{array}$ & $\begin{array}{l}+ \\
+ \\
+ \\
+ \\
+ \\
+ \\
+ \\
+ \\
+ \text { (rare) }\end{array}$ & $\begin{array}{l}+ \\
+ \\
+ \\
+ \\
- \\
- \\
+ \\
-\end{array}$ \\
\hline
\end{tabular}

${ }^{\star}$ Hepatitis non $\mathrm{A}$-non $\mathrm{B}$.

3) Hepatitis Delta Virus (HDV)

4) Human Parvovirus

5) Hepatitis C Virus (HCV).

Various virus-inactivation procedures are currently employed for the purpose of optimising the safety of plasma products.

\section{VIRUS INACTIVATION PROCEDURE WITH IVIg}

Virus removal by Cohn-fractionation, with particular reference to HIV, has already been comprehensively described. ${ }^{12}$

The occurrence of $\mathrm{HCV}$ infection after IVIg treatment led to safety improvement in the manufacturing procedures.

Virus removal is achieved by the following measures which are employed in addition to the cold ethanol fractionation:

1) Reduction in the $\mathrm{pH}$ values to 4.25 with subsequent incubation of the finished preparation at $\mathrm{pH} 4.25$ and $25^{\circ} \mathrm{C}$ for 24 days

2) Beta-propiolactone treatment

3) Pasteurisation, 10 hours at $60^{\circ} \mathrm{C}$

4) Oxidative $S$-sulphonation

5) Hydrolases bound to fixed phases.

6) Solvent/detergent treatment with TNBP (tri-(n-butyl)-phosphate)/Na-cholat resp. Tween 80 and sodium cholate.

Experience has shown that the chemical or physical virus inactivation procedures employed in the manufacturing process impair the development of the IVIg preparations. As a rule, additional auxiliary substances and stabilisers must then be used to prevent changes in the structure and functional capacity of the individual native antibody molecule and also to prevent a change in the composition of subclasses $\operatorname{IgG}_{1-4}$

\section{VALIDATION}

Various studies are performed to validate the viral inactivation potential of a manufacturing process. Such studies consist of testing every single manufacturing step for its viral inactivation potential with regard to a specific virus.

As a rule, a defined quantity of virus is added to the starting material. Test samples are run in duplicates which are treated identically. The respective samples are examined for their viral content at the end of each selected manufacturing step. The value found is then compared with the quantity of virus which was added initially to the starting material.

Model viruses, as well as host-specific
Table 3 Example of a reduction through Cohnfractionation

\begin{tabular}{lr}
\hline Viruses & Reduction $\left(\log _{10}\right)$ \\
\hline HIV-1 (HIV-2) & $>15 \cdot 6$ \\
Bovine viral diarrhoea virus (HCV) & $6 \cdot 6$ \\
Pseudorabies virus (HBV) & $14 \cdot 4$ \\
Simian virus 40 & $5 \cdot 1$ \\
\hline
\end{tabular}

viruses, are selected for the studies concerned.

1) Bovine viral diarrhoea virus

Model virus for $\mathrm{HCV}$, enveloped RNA virus which can be slightly inactivated by heat, is sensitive to organic solvents, acidlabile, base-proof.

2) Pseudorabies virus

Model virus for $\mathrm{HBV}$, enveloped DNA virus, relatively thermolabile, sensitive to organic (lipophilic) solvents and extreme pH values.

3) Simian virus 40

Model virus for non-enveloped DNA viruses, very stable virus, resistant to ether, $2 \%$ phenol and $50 \%$ ethanol.

4) $H I V-1$

Retrovirus, serves at the same time as a model virus for HIV-2.

The data for the elimination rates are expressed logarithmically. The reduction factor is calculated using the following formula:

Total amount of virus in the starting material Total amount of virus in the test sample

Table 3 shows an example of typical elimination rates using Cohn-fractionation as the sum of the individual manufacturing steps (overall reduction factor).

While the elimination rates of the model virus for HIV and HBV appear to be suffcient, the reduction in $\mathrm{HCV}$ and nonenveloped viruses is distinctly lower. It has already been mentioned that due to the unlikely risk of viral infection from IVIg, these preparations have been given little attention. From a current standpoint, however, the introduction of a further manufacturing step for the purpose of viral inactivation - in addition to the viral elimination potential of the Cohn-fractionation procedure-should be made a requirement for the manufacture of IVIg preparations.

It has also been demonstrated that commercial and paid blood donations increase the risk of infection with hepatitis pathogens. It has been shown that infection with hepatitis considerably increases in relation to the number of paid blood donors. ${ }^{13}$ The EC commission guidelines therefore recommend using unpaid voluntary donors. ${ }^{8}$ This recommendation also provides a better guarantee of a balanced antibody spectrum of the IVIg preparations for a given population. ${ }^{14}$

\section{Conclusion}

The 1982 WHO requirements form the minimum basis world wide for the quality and 
safety of IVIg. Because the range of application of IVIg has expanded considerably in the last 10 years, there is a fundamental requirement to introduce further active virus inactivation procedures which supplements the virus elimination achieved with, for example, the Cohn-Oncley-fractionation method.

This applies above all for IVIg preparations which are not obtained from blood and plasma from unpaid voluntary donors in the framework of a national self-supply, since such sources are characterised by a higher risk of infection-particularly when they are collected in social fringe groups of population centres. ${ }^{13}$

Because the various active virus inactivation procedures exhibit different specificity of action for certain viruses, an IVIg preparation would be ideal-according to current knowledge - if it were obtained nationally from voluntary, unpaid blood or blood plasma donations and subjected to two active virus elimination procedures with different mechanisms of action.

1 Berkmann SA, Lee ML, Gale RP. Clinical Uses of Intravenous Immunoglobulin. Sem Hematol 1988;25(2): Intraveno 158 .

2 Berkmann SA, Lee ML, Gale RP. Clinical Uses of
Intravenous Immunoglobulin, Review. Ann Intern Med 1990;112:278-92.

3 Imbach P, ed. Immunotherapy with intravenous immunoglobulins. London: Academic Press, 1991.

4 Morell A, Nydegger UE, eds. Clinical use of intravenous immunoglobulins. London: Academic Press, 1986.

5 Nydegger UE, Rieben R, Kazatchkine MD. Intravenöse Immunglobulintherapie als Beeinflussungsmöglichkeit von autoimmunen Prozessen. In: Salama A, Kurrle R, eds. Infektion und Autoimmunerkrankungen II, Univ.Verlag Jena 1993:15-27.

6 WHO Bulletin. Appropriate uses of human immunoglobulin in clinical practice. Memorandum from an IUIS/WHO meeting 1982;60:43-7.

7 WHO technical Report Series 1989, No 786, Annex 4 Requirements for the collection, processing, and quality control of blood, blood components, and plasma derivatives.

8 Council Directive 89/381/EEC.

9 Cohn EJ, Strong LE, Hughes WL, Mulford DJ, Ashworth JN, Melin M, Taylor HL. Preparation and properties of serum and plasma proteins: a system for the separation into fractions of the protein and lipoprotein components of biological tissues and fluids. $\mathcal{F}$ Am Chem Soc 1946;68: 459-75.

10 Prince AM, Horowitz B, Horowitz MS, Zang E. The development of virus-free labile blood derivatives. Eur $\mathcal{f}$ Epidemiol 1987;3(2):103-18.

11 Cuthbertson B, Reid KG, Foster PR. Viral Contamination of human plasma and procedures for preventing virus transmission by plasma products. In: Harris $J \mathbf{R}$ virus transmission by plasma products. In: Harris $\mathrm{JR}$, ed. Blood separatio

12 Morgenthaler JJ. Effect of ethanol and viruses. Curr. Stud. Hematol. Blood Transfus. 1989;56:109-21.

13 Chalmers TC. Carrier blood donors. In: Vyas GN, ed. Hepatitis and blood transfusion. New York and London Grune and Stratton 1972.

14 Albrecht, H. Einsahmöglichkeiten von intravenösen Immunglobulien in der Therapie erwachsener HIV infizierter Patienten. Sonderdruck aus: AIDS. Eine Krankheit Wird behandelbar. Landsverg/Leck: Ecomed Verlag, 1993.

15 Yap PL. Clinical applications of intravenous immunoglobulin therapy. London: Churchill Livingstone, 1992. 